\title{
Spend-and-Tax Adjustments and the Sustainability of the Government's Intertemporal Budget Constraint
}

\author{
Gabriella Legrenzi \\ Costas Milas
}

CESIFO WORKING PAPER NO. 2926

CATEgory 1: Public FinAnCE

JANUARY 2010

Presented at CESifo Area Conference on Public Sector EConomics, April 2009
An electronic version of the paper may be downloaded
- from the SSRN website:
- from the RePEc website:
www.SSRN.com
www.RePEc.org
- from the CESifo website:
www.CESifo-group.org/wp 


\title{
Spend-and-Tax Adjustments and the Sustainability of the Government's Intertemporal Budget Constraint
}

\begin{abstract}
We apply non-linear error-correction models to the empirical testing of the sustainability of the government's intertemporal budget constraint. Our empirical analysis, based on Italy, shows that the Italian government is meeting its intertemporal budget constraint, in spite of the high levels of public debt. Nevertheless, the burden of correcting budgetary disequilibria is entirely carried out by changes in the average tax rate, with a weakly exogenous government spending, possibly determined by the political process. We document some rigidities of the tax instrument, in terms of downward inflexibility of the average tax rate, not only with respect to its long-run level, but also during periods of decreasing economic growth. Further, we provide some evidence in favour of a non-linear adjustment towards a sustainable long-run equilibrium, as the average tax rate adjusts faster the farther away it is from the equilibrium.
\end{abstract}

JEL-Code: C32, C51, C52, H20, H50.

Keywords: intertemporal budget constraint, sustainability, non-linear error-correction, fiscal reaction function.

\author{
Gabriella Legrenzi \\ Department of Economics \\ Keele University \\ Keele ST5 5BG \\ United Kingdom \\ g.d.legrenzi@keele.ac.uk
}

\author{
Costas Milas \\ Department of Economics \\ Keele University \\ Keele ST5 5BG \\ United Kingdom \\ c.milas@econ.keele.ac.uk
}

December 31, 2009

Former versions of this paper have been presented at the CESifo Area Conference on Public Sector Economics, the World Congress of the Public Choice Society, the annual meeting of the Society for Non-Linear Dynamics and Econometrics, the North American Summer Meeting of the Econometric Society, and the Annual Meeting of the Royal Economic Society. We would like to thank all participants for useful remarks and suggestions. Financial support from CESifo is gratefully aknowledged. 


\section{Introduction}

The Treaties governing the European Monetary Union impose some relevant constraints on the fiscal policy of member states, limiting their autonomy in creating excessive debts and deficits ${ }^{1}$, as fiscal disequilibria in one state can impose relevant negative externalities on the stability of the other member countries, as well as on the overall credibility of the common monetary policy. On the other hand, given the common monetary policy, the correction of idiosyncratic shocks is assigned to the fiscal instrument alone, imposing further pressures on the fiscal policy of member countries.

The issue of the sustainability of the public finances of the EMU member countries has consequently received an increasing attention, but less attention has been paid to the issue of how the sustainability is achieved, that is, how do budgetary authorities adjust fiscal policies to achieve/maintain a sustainable path of public debt and deficit. Focussing on this adjustment by applying linear and non-linear error-correction models is the main purpose of our paper.

Our empirical analysis is based on Italy, which provides an interesting case as it joined the European Monetary Union in 1999, in spite of a stock of public debt of around $113 \%$ of nominal GDP (against the $60 \%$ level required by the Maastricht Treaty), and whose public accounts are often under scrutiny for struggling to comply with the European Stability and Growth Pact ${ }^{2}$, as well

\footnotetext{
${ }^{1}$ Article 104 of the Maastricht Treaty (1993) imposes a ceiling to debt and deficit of $60 \%$ and 3\% of domestic GDP, respectively, as conditions for the admissions to the EMU. The European Stability and Growth Pact (ESGP), signed in 1999 and revised in 2005, reinforces the $3 \%$ ceiling for the government deficit of member countries, establishing an excessive deficit procedure for violations of the rule.

${ }^{2}$ In particular, in July 2005 the Council of the European Union concluded, under the excessive deficit procedure, that Italy had an excessive deficit and reccomended a correction by 2007 . In June 2008 the Council closed the procedure, as the Italian deficit had "been brought below the $3 \%$ threshold in a credible and sustainable manner" (10127/1/09/REV1). In October 2009, a new procedure has been opened (IP/09/1428).
} 
as for subsequent downgradings of its sovereign debt by the main credit ratings agencies $^{3}$.

In this paper, we address three main relevant policy questions. First, is the Italian government's intertemporal budget constraint respected? Second, is the process of fiscal adjustment equally shared by changes in revenues and changes in government spending? Third, does fiscal adjustment vary with the sign and magnitude of disequilibria and/or with the state of the economy?

Our proposed approach provides a number of interesting findings.

The Italian government's intertemporal budget constraint is formally respected, in spite of the high levels of public debt. Nevertheless, the burden of correcting budgetary disequilibria is entirely carried by changes in the average tax rate, rather than changes in government spending or policy mixes. Government spending is shown to be weakly exogenous, pointing to a "spend-and-tax" adjustment, where the level of spending appears to be determined by the political process. We also find that taxes adjust more rapidly when deviations from the equilibrium level get larger, as well as provide some evidence of downward inflexibility of taxes, when these are above their long-run level. Further, taxes increase rapidly during periods of accelerating economic growth, but are downward inflexible during periods of decreasing economic growth.

The paper is organised as follows. Section 2 discusses the theoretical background of the sustainability of the government's intertemporal budget constraint. Section 3 presents our long-run sustainability analysis, while Section 4 reports the fiscal authorities' reaction function to fiscal disequilibria. Section 5 presents the main conclusions of the paper, as well as suggestions for further

\footnotetext{
${ }^{3}$ Standard \& Poor's now rates the Italian long term sovereign debt with an A+ and Fitch with a $\mathrm{A}-$, against the AA rating of 1998 .
} 
research.

\section{The Sustainability of the Government's In- tertemporal Budget Constraint.}

Following Walsh (2003) and Bohn (2008), the nominal one-period consolidated government-sector budget identity is given by:

$$
G_{t}+i_{t-1} B_{t-1}=T_{t}+\left(B_{t}-B_{t-1}\right)
$$

Where $G_{t}$ represents the general government expenditure, net of interest payments, $B_{t}$ is the stock of government bonds sold to the private market, $i_{t-1} B_{t-1}$ are the interest payments on the outstanding debt ${ }^{4}$, and $T_{t}$ are the tax revenues. All variables are in nominal terms, and, for simplicity, we ignore the effect of seigniorage and surprise inflation.

As all policy debates are in terms of GDP shares, we divide equation (1) by nominal output, $Y_{t}$, obtaining:

$$
\frac{G_{t}}{Y_{t}}+\frac{i_{t-1} B_{t-1}}{Y_{t}} \frac{Y_{t-1}}{Y_{t-1}}=\frac{T_{t}}{Y_{t}}+\frac{B_{t}}{Y_{t}}-\frac{B_{t-1}}{Y_{t}} \frac{Y_{t-1}}{Y_{t-1}}
$$

Letting $\mu_{t}$ be the output growth rate, and $\pi_{t}$ the inflation rate, and rearranging, we obtain the following compact debt dynamics:

$$
b_{t}=g_{t}-t_{t}+\left(1+\bar{r}_{t-1}\right) b_{t-1}
$$

where the lowercase letters denote the corresponding variables in real to GDP terms, and $\bar{r}_{t-1} \equiv \frac{1+i_{t-1}}{\left(1+\mu_{t}\right)\left(1+\pi_{t}\right)}-1$.

\footnotetext{
${ }^{4}$ We assume the debt to be one-period in maturity, so that debt issued in period $t-1$ earns the nominal interest rate $i_{t-1}$.
} 
Assuming a positive $r$, and constant over time, and taking the conditional expectations of the variables, the path of the public debt for an arbitrary sequence of future government spending and taxes is given by:

$$
E_{t}\left[b_{t+n}\right]=\sum_{j=0}^{n}(1+r)^{n-j} E_{t}\left[g_{t+n}\right]-\sum_{j=0}^{n}(1+r)^{n-j} E_{t}\left[t_{t+n}\right]+(1+r)^{n} b_{t}^{*}
$$

where $b_{t}^{*}=(1+r) b_{t-1}$ is the debt at the start of period $t$.

Rearranging, we obtain:

$$
b_{t}^{*}=\sum_{j=0}^{n}(1+r)^{n-j-n} E_{t}\left[t_{t+n}\right]-\sum_{j=0}^{n}(1+r)^{n-j-n} E_{t}\left[g_{t+n}\right]+(1+r)^{-n} E_{t}\left[b_{t+n}\right]
$$

Assuming this discounted sum converges and taking the limit $n \rightarrow \infty$, we get:

$$
b_{t}^{*}=\sum_{j=0}^{\infty}(1+r)^{-j} E_{t}\left[t_{t+n}\right]-\sum_{j=0}^{\infty}(1+r)^{-j} E_{t}\left[g_{t+n}\right]+\lim _{n \rightarrow \infty}(1+r)^{-n} E_{t}\left[b_{t+n}\right]
$$

Equation (6) represents the government's intertemporal budget constraint (IBC).

Defining the primary deficit as $\Delta_{t}=\left(g_{t}-t_{t}\right)$, we obtain from the above:

$$
b_{t}^{*}=-\sum_{j=0}^{\infty} E_{t}\left[\Delta_{t+n}\right](1+r)^{-j}+\lim _{n \rightarrow \infty}(1+r)^{-n} E_{t}\left[b_{t+n}\right]
$$

The IBC is met when the initial debt equals the expected present value of future surpluses. This implies the imposition of the following transversality condition:

$$
\lim _{n \rightarrow \infty} \frac{b_{t+n}}{(1+r)^{n}}=0
$$


i.e. that the government does not adopt Ponzi games, by continuously relying on the issue of new debt to pay the interest on the old debt.

The above condition can be interpreted as a bondholders' transversality condition to be willing to hold public debt, as it reassures them about the solvency of the government.

The empirical testing of the sustainability of the government's IBC is generally based on the analysis of the past behaviour of the fiscal policy variables, and several empirical tests have been suggested in the literature, based on the stationarity of debt/deficit and/or on the cointegration between public revenues and expenditures (see, e.g., .Hamilton and Flavin, 1986, Trehan and Walsh, 1988 and 1991, Wilcox, 1989, Hakkio and Rush, 1991, Quintos, 1995, Uctum and Wickens, 2000, and Bohn, 2006). More recent work by Chortoreas et al. (2008) introduces a non-linear stationary model as alternative hypothesis, while a panel unit root/cointegration approach is used by Afonso and Rault (2008) and a multicointegration approach is used by Leachman et al. (2005).

Following Afonso (2005), we initially test for cointegration between the GDP shares of government spending and revenues, i.e. $G O V$ and $T A X$. TAX is the nominal general government revenues on nominal GDP, GOV denotes the government share (i.e. nominal general government expenditure on nominal $G D P):$

$$
T A X_{t}=a+b G O V_{t}+u_{t}
$$

We do not transform our variables into logs, as this will affect the cointegration (Banerjee et al., 1993). Taking logs of a series magnifies its fluctuations near zero, whereas sustainability is primarily concerned on how fiscal policy 
recovers from high values of debt and outlays (Bohn, 2008). Given that both revenues and spending are highly dependent on aggregate income, our short-run models of Section 4 also allow for additional effects from nominal GDP.

In case the null of no cointegration between TAX and GOV cannot be rejected at conventional levels of statistical significance, then the governemnt's IBC is not met and consequently the fiscal policy is considered unsustainable. In case TAX and GOV result cointegrated, with and estimated $b=1$, then the government's IBC is respected. In case there is cointegration between TAX and GOV, but $b<1$, then government spending grows faster than government revenues, and the fiscal policy in this case might not be sustainable.

There are nevertheless some shortcomings associated with the empirical testing of the sustainability of the government's IBC in a cointegration/unit root analysis. All the sustainability tests are necessarily backward looking, as they look at the past behaviour of the public finance variables. We might argue, on the other hand, that the fact that a country has consistently conducted its public finances in a sustainable way can provide a good indicator for its future behaviour. Further, the sustainability tests do not take into account the assets owned by the government, which in principle could be sold to the private market. Finally, the sustainability tests implicitly consider the interest rate as stationary.

Previous empirical evidence on the sustainability of the Italian IBC is controversial: Feve and Henin (2000), Afonso (2005) and Galli and Padovano (2008), all find that the Italian government finances are on an unsustainable path. A different conclusion is reached by Greiner et al. (2007) and Uctum et al. (2006), who provide evidence in favour of the sustainability of the Italian government's IBC, in spite of the high levels of public debt. 


\section{The empirical model: The long-run analysis.}

\subsection{Data and empirical methodology.}

Given the discussion above, we empirically model the budgetary decisions of Italy, based on annual Italian data over the period 1960 to $2008^{5}$. Our use of low frequency data allows us to capture the discretionary changes in budgetary policy, that would be ruled out by higher frequency data (see e.g. Blanchard and Perotti, 2002). Further, higher frequency data, that would provide higher degrees of freedom in our estimates, are only available for a much shorter time span.

Figure 1 plots $T A X, G O V$ and $\triangle T A X, \triangle G O V$. We notice that both the revenues and expenditures shares on GDP have considerably grown over time, reaching their peaks in the Nineties. In particular, at the start of our sample, tax revenues accounted for $27 \%$ of national GDP, peaking in the late Ninenities at around $47 \%$ of GDP. Government spending has followed a similar ascending pattern, accounting for $28 \%$ of GDP at the start of our sample, and peaking in the early Nineties at $56 \%$ of GDP. Preliminary analysis using different unit root tests suggests that both the revenue and the expenditure series are nonstationary in levels ${ }^{6}$.

In order to test for cointegration between revenues and expenditures, we estimate a Vector Error Correction Model (VECM; see Johansen, 1988) of the form:

\footnotetext{
${ }^{5}$ The dataset is taken from AMECO and a full description of the variables can be found in the Data Appendix.

${ }^{6}$ We have conducted the following unit root tests: Augmented Dickey-Fuller (Dickey and Fuller, 1979), Phillips-Perron (1998), Kwiatkoski-Phillips-Schmidt-Shin (1992), and Ng-Perron (2001). To save space, we do not report in the paper these results, but are available on request from the authors.
} 


$$
\Delta y_{t}=\sum_{i=1}^{k-1} \Gamma_{i} \Delta y_{t-1}+\Pi y_{t-1}+\mu+\varepsilon_{t}
$$

where $y_{t}=[T A X, G O V]^{\prime}$ is the set of non-stationary I(1) variables discussed above, $\varepsilon_{t} \sim \operatorname{niid}(0, \Sigma), \mu$ is a drift parameter, and $\Pi$ is a $(p * p)$ matrix of the form $\Pi=\alpha \beta^{\prime}$, where $\alpha$ and $\beta$ are $(p * r)$ matrices of full column rank, with $\beta$ containing the $r$ cointegrating vectors and $\alpha$ carrying the corresponding loadings in each of the $r$ vectors. The VAR approach is preferred here as it provides the advantage of allowing to model both revenues and expenditures as potentially endogenous.

We set the lag length $k$ equal to 2 based on the Akaike Information Criterion. We test for cointegration between revenues and expenditures using Johansen's (1988) maximal eigenvalue $(\lambda$-max $)$ and trace $(\lambda$-trace $)$ statistics. To account for our small sample, both tests use a small sample correction (for exact mathematical formulas, see e.g. Doornik and Hendry, 2000, p.282). Both the $\lambda$-max and the $\lambda$-trace statistics reject the null of no cointegration in favor of one cointegrating vector between revenues and expenditures ${ }^{7}$.

We can now test some relevant policy questions, namely: (a) is the Italian government's IBC respected? (b) is the burden of correcting budgetary disequilibria equally shared by changes in revenues and changes in government spending?, and (c) what is the speed of the process of correcting budgetary disequilibria?

Hypotheses (a) and (b) can be tested via a Likelihood Ratio (LR) test, which is distributed as a $\chi^{2}(1)$ under the null hypotheses of (i) proportionality between revenues and expenditures and (ii) equal adjustment coefficients,

\footnotetext{
${ }^{7}$ The $\lambda$-max and $\lambda$-trace statistics are equal to $10.23(\mathrm{p}$-value $=.07)$ and $13.82(-$ value $=.02)$, respectively. The empirical evidence in favour of one cointegrating vector is therefore stronger for the $\lambda$-trace test. The p-values are taken from MacKinnon et al. (1999).
} 
respectively.

The first hypothesis is not rejected, as the LR gives a value of 0.954 (pvalue $=0.33)$. The second hypothesis is rejected, as the $L R$ gives a value of 7.35 (p-value $=0.00)$.

Given that the adjustment coefficient on $G O V$ is insignificantly different from zero at 5 percent, as the LR test gives a value of $2.44(\mathrm{p}$-value $=0.12)$, government share is weakly exogenous in our model.

To check the robustness of the estimated long-run results, we also used the fully modified (semi-parametric) OLS method of Phillips and Hansen (1990) for estimation of a single cointegrating vector when there is endogeneity between the $T A X$ and $G O V$ variables. The Phillips and Hansen (1990) procedure provided almost identical results; in particular, the estimate on $G O V$ was equal to 0.951 (standard error $=0.066$ ). Figure 2 plots the deviations from the estimated (restricted) relationship. Deviations appear at times quite persistent, suggesting the possibility of non-linear error-correction adjustment, discussed later.

Recursive estimation is used to examine the stability of our cointegrating results and therefore assess any changes over time in the estimated relationship between the tax revenue and government shares of GDP. Figure 3 plots the recursively estimated $\lambda$-trace and $\lambda$-max test statistics divided by the corresponding $5 \%$ critical values. Values of these fractions greater than one indicate stability of the cointegration results over time. The recursively estimated $\lambda$ trace test suggests cointegration in all cases but one. On the other hand, the recursively estimated $\lambda$-max test indicates cointegration only up to 1995 ; however, from 2000 onwards the fraction value reverts back to one slowly, signalling a higher attention towards IBC sustainability.

Recursive estimation is also used to assess how the coefficient on $G O V$ 
has changed over time. Figure 4 plots the recursively estimated coefficient $\pm 2 \times$ standard errors. The time-path of the coefficient on the government share of GDP indicates that long-run revenue movements have been less sensitive to expenditure movements in the mid 1980s and mid 1990s, after which one-by-one movements become a norm, confirming the higher attention paid to the IBC in recent years.

The speed of the fiscal consolidation process (question (c) above), can be inferred from the analysis of the impulse response of the cointegrating relationship to system-wide shocks (this is the "persistence profile analysis" in Pesaran and Shin, 1996). From Figure 5, this converges to zero rather slowly with 90 percent of the adjustment completed after 6 years. Deviations from the estimated cointegrating relationship are therefore eliminated very slowly, rendering the process of fiscal consolidation rather slow.

\subsection{Policy implications of the long-run analysis}

What are the economic implications of the above statistical tests? The presence of cointegration with a cointegrating vector of $(1,-1)$ points to a stable long-run co-movement of the revenues and expenditure shares of GDP, which is generally interpreted, as discussed in Section 2, as an evidence for the sustainability of fiscal policy, that is, for the ability of the Italian government to meet its IBC.

Weak exogeneity of government spending implies that the short-run adjustment to correct budgetary disequilibria is done by changes in tax policy rather than changes in government spending or even policy mixes. Government spending appears therefore to be exogenously decided by the political process, with taxes adjusting consequently. This result is consistent with the spend-and-tax 
adjustment studied by Peacock and Wiseman (1979), and in line with previous studies on Italy, adopting a different specification of the model (see, e.g. Koren and Stiassny 1998, Alesina and Perotti, 1996).

A slow fiscal adjustment process operating through changes in taxes rather than changes in government spending could be related to public expenditure rigidities, not only due to multi-annual contracts and planning, but also due to strong resistance against expenditure reductions arising both from the demandside and bureaucratic powers (see OECD, 2005, and Legrenzi and Milas, 2002). The political instability of the country, typically associated with multi party coalition governments ${ }^{8}$ and frequent general elections ${ }^{9}$, renders problematic the achievement of the necessary consensus to politically unpopular spending cuts, favoring therefore the prevalence of the adjustment via the tax-system, rather than a policy mix. The necessary reforms of the welfare state, and of the pensions system in particular, although debated for several years, are very slowly put into place, due to strong public opposition in the form of widespread general strikes (Reviglio, 2001). The low level of independence of the Italian Central Bank for most of the sample considered, also resulted in a soft-budget constraint for the central government, favoring expenditure growth (see Koren and Stiassny, 1998).

A burden of fiscal consolidation entirely carried by taxes can have a serious detrimental impact on the economy. Daveri and Tabellini (2000) identify tax increases on labour and profits as the main cause of declining economic growth and expansion of the shadow economy. This is certainly true for Italy where

\footnotetext{
${ }^{8}$ For a more detailed analysis of the link between coalition governments and lower fiscal responsibility, see Roubini and Sachs (1989), Grilli et al. (1991) and Alesina and Perotti (1995).

${ }^{9}$ It is interesting to notice that in the time span considered here, Italian political life saw 47 governments and 14 general elections.
} 
the black market economy accounted for $25.8 \%$ of official GDP in 1994, against $12.4 \%$ for the UK, $14.3 \%$ for France and $9.4 \%$ for the US (see Schneider and Enste, 2000). Further, Alesina and Ardagna (1998) show that fiscal consolidations based on tax increases alone are short-lived, unlike fiscal consolidations based on spending cuts. Bertola and Drazen (1993), Sutherland (1997) and Ardagna (2004) also argue that spending cuts can have an expansionary (non-Keynesian) effect on the economy, as opposed to increases in taxes.

\section{The Adjustment towards Sustainability}

\subsection{Linear adjustment}

As the null of cointegration between the tax and the expenditure shares of GDP cannot be rejected at conventional levels of statistical significance, we proceed to estimate the corresponding error-correction model, to understand how yearto-year changes in taxes adjust the economy back towards a sustainable longrun equilibrium, conditional on government spending which resulted weakly exogenous in the previous section. We can intepret this error-correction model as the fiscal authorities' reaction function to budgetary disequilibria, in the sense of deviations of taxes and spending from their long run equilibrium which embeds a sustainable government's IBC.

We initially estimate the short-run adjustment of taxes within a linear error correction model To account for the possibility of European Monetary Union effects, we also tried a dummy variable, taking the value of 1 from 1993 (when the Maastricht Treaty was agreed) onwards and 0 elsewhere. The dummy variable turned out to be statistically insignificant, implying that the adjustment of the

Italian public finances did not take place through structural changes in the 
revenue-expenditure patterns ${ }^{10}$.

To capture the effects of economic and accelerating economic growth we also considered current and lagged values of $\Delta G D P_{t-1}$ and $\Delta^{2} G D P_{t-1}$ as extra regressors. We found some weak effect from $\Delta^{2} G D P_{t-1}$ only in the non-linear error correction model reported in the following section.

The OLS estimates of the parsimonious linear error-correction model are reported in Table 1(i).We tested and found significant non-linearities in the residuals of the linear error correction model, using the Brock, Dechert and Sheinkman (BDS, 1996) test statistic. The test is also discussed in Escribano $(2004)^{11}$. For this reason, we proceed to re-estimate the error-correction model by allowing for asymmetric and non-linear error correction adjustment ${ }^{12}$.

\subsection{Asymmetric and Non-linear Adjustment}

The asymmetric error correction model is obtained by taking the deviations of the cointegrating vector $\mathrm{CV}_{t-1}$ around its mean value, and partitioning them into their positive and negative components (denoted by $\mathrm{CV}_{t-1}^{+}$and $\mathrm{CV}_{t-1}^{-}$, respectively). Results for the parsimonious asymmetric error-correction model are reported in Table 1(ii). The results indicate that the speed of adjustment varies depending on whether the estimated relationship is above or below its equilibrium. The point estimates suggest that when taxes are lower than equilibrium, they increase rapidly. On the other hand, when taxes are higher than equilibrium, they fall slowly. Notice that the coefficient on $\mathrm{CV}_{t-1}^{-}$is more than

\footnotetext{
${ }^{10}$ Italy qualified to the European Monetary Union despite failing the debt criterion. Economic adjustment was mainly driven by changes in monetary policy. In 1997, a "European tax" was imposed on private households, as a one-off measure, and some "budgetary gimmicks" were used in order to qualify for the deficit criterion (see e.g. Reviglio, 2001).

${ }^{11}$ Results available on request.

${ }^{12}$ Asymmetric and non-linear error correction models have been introduced by Escribano (1986). See also Granger and Lee (1989), Escribano and Granger (1998), Escribano and Pfann (1998), Escribano and Aparicio (1999), and Escribano and Mira (2002), amongst others.
} 
twice as large (in absolute value) as the coefficient on $\mathrm{CV}_{t-1}^{+}$. Nevertheless, equality of the coefficients on $\mathrm{CV}_{t-1}^{+}$and $\mathrm{CV}_{t-1}^{-}$is not rejected based on an Ftest $(\mathrm{p}$-value $=0.38)$. Hence, in economic terms our results point to downward inflexibility of taxes. Nevertheless, in terms of statistical tests, these results are not clear-cut.

To obtain the non-linear error correction model, we add to the linear model of Table 1(i) the squared and cubed values of the error-correction regressor, that is, $\mathrm{CV}_{t-1}^{2}$ and $\mathrm{CV}_{t-1}^{3}$. This type of non-linearities allows for a faster adjustment when deviations from the equilibrium level get larger. Results for the parsimonious non-linear error correction are reported in Table 1(iii). The p-value of the $\mathrm{F}$ test for the statistical significance of the $\mathrm{CV}_{t-1}^{3}$ regressor is equal to 0.00 , and the $\mathrm{p}$-value of the $\mathrm{F}$ test for the joint significance of the $\mathrm{CV}_{t-1}^{2}$ and $\mathrm{CV}_{t-1}^{3}$ regressors is equal to 0.01 , indicating (at the 5 percent level of statistical significance) that adjustment back to equilibrium is stronger for large disequilibrium deviations. We also report a weak positive effect on taxes from lagged accelerating economic growth, possibly capturing the built-in progressivity of the fiscal system. We return to this issue more in detail below.

A comparison of the regression standard errors across models indicates that the non-linear model has a better fit. This is also confirmed by recursive parameter stability tests (available by the authors on request).

Figure 6a and Figure 6b plot the asymmetric and non-linear adjustments against the cointegrating vector, respectively. Figure 6a shows an asymmetric adjustment of taxes, as deviations above equilibrium are corrected slower compared to deviations below equilibrium. On the other hand, we notice from Figure $6 \mathrm{~b}$ that once disequilibrium deviations get larger, adjustment back to equilibrium becomes stronger. 
To assess further the differences amongst the estimated models, we take a closer look at the contribution of the error correction terms to changes in the tax share of GDP. To do this, we plot in Figure 7 the values of the error correction components of the linear, asymmetric and non-linear equations across time. The linear model appears to be correcting more slowly with respect to the asymmetric and non-linear ones, both when above and when below the equilibrium. Of the three models, the non-linear one embeds a faster adjustment.

The presence of these asymmetries suggests the opportunity of analyzing further the behavior of taxes in different phases of the economic cycle. In particular, we investigate the possibility of asymmetric effects from accelerating and decreasing economic growth on taxes, given the weak positive effect from lagged accelerating growth $\left(\Delta^{2} \mathrm{GDP}_{t-1}\right)$ on taxes reported in Table 1(iii). For this purpose, we partition $\Delta^{2} \mathrm{GDP}_{t-1}$ into its positive and negative components (denoted by $\Delta^{2} \mathrm{GDP}_{t-1}^{+}$and $\Delta^{2} \mathrm{GDP}_{t-1}^{-}$, respectively). Then we re-estimate the non-linear model of Table 1 (iii) where we replace $\Delta^{2} \mathrm{GDP}_{t-1}$ with $\Delta^{2} \mathrm{GDP}_{t-1}^{+}$ and $\Delta^{2} \mathrm{GDP}_{t-1}^{-}$as separate regressors. The coefficient on $\Delta^{2} \mathrm{GDP}_{t-1}^{+}$is estimated at 0.110 (t-ratio $=1.22)$. The coefficient on $\Delta^{2} \mathrm{GDP}_{t-1}^{-}$is estimated at 0.040 (t-ratio $=.16$ ) whereas the estimates of the remaining regressors are almost identical to those of Table 1(iii). GDP symmetry is not rejected based on an F-test $(\mathrm{F}=0.41$, p-value $=0.53)$. On the other hand, the joint hypothesis of symmetric GDP effects and linear error correction adjustment (in terms of zero effects from $\mathrm{CV}_{t-1}^{2}$ and $\left.\mathrm{CV}_{t-1}^{3}\right)$ is rejected at 10 percent $(\mathrm{F}=2.86$, pvalue $=0.07)$. Hence, there is some evidence of downward inflexibility of taxes during periods of decreasing economic growth as the coefficient on $\Delta^{2} \mathrm{GDP}_{t-1}^{-}$ is four times lower than the coefficient on $\Delta^{2} \mathrm{GDP}_{t-1}^{+}$, which in turn is statistically insignificant. We believe that this result deserves more attention and 
possibly further analysis in the direction of planning an adequate strategy of tax-smoothing, to avoid taxes to become more pressing during economic downturns.

This result strengthens our conclusions with respect to the weaknesses of the spend-and-tax adjustment, suggesting policy-makers to adopt a higher degree of caution when pursuing measures of fiscal consolidation relying exclusively on a unique instrument.

\section{Conclusions}

This paper performs an empirical analysis of the sustainability of the Italian public finances between 1960 and 2008. We provide robust evidence in favour of cointegration between taxes and government spending, with a cointegrating vector of $(1,-1)$. This result is generally interpreted as that the Italian government's IBC is sustainable. We find nevertheless that the year-to-year adjustments to correct budgetary disequilibria are made entirely via changes in taxes, rather than spending cuts or policy mixes, as the government spending share on GDP resulted weakly exogenous. This result is in line with the spend-and-tax model, where government spending is determined by the political process and taxes adjust consequently. We also document some rigidities in the tax instrument, particularly in terms of downward inflexibility of the average tax rate during periods of decreasing economic growth, pointing to a regressive use of the tax instrument.

Taken together, our results point to a relevant wekness of the Italian public finances, questioning the emphasis put on the sustainability analysis alone in previous studies, and confirming the importance of analysing the adjustment process towards a sustainable IBC. 
Our work can be extended in several ways. Teräsvirta (1998) pointed out that non-linear models with quadratic and cubic error correction terms are firstorder approximations to smooth transition autoregression models, where the transition mechanism between different regimes is driven by the disequilibrium error. In the context of our public finance model, it would be interesting to estimate a two-regime smooth transition model where adjustment takes place in every period but the speed of the adjustment as well as the impact of the lagged values of expenditure and taxes vary conditional on whether disequilibrium deviations from the expenditure/taxes relationship are large or small.

It would also be interesting to examine whether non-linear adjustment can be elevated into a stylized fact, by considering tax and government spending adjustment in other countries, as well as at a local government level. If it can, then non-linearities in taxes and spending might be incorporated into existing non-linear models of fiscal policy (see e.g. Giavazzi et al., 2000). We intend to address these issues in future research.

\section{References}

[1] Afonso A. (2005). Fiscal Sustainability: the Unpleasant European Case. FinanzArchiv, 61 (1), 19-44.

[2] Afonso A., Rault C. (2008). What Do We Really Know about Fiscal Sustainability in the EU? A Panel Data Diagnostic. CESifo Working Paper No.2226, February 2008.

[3] Alesina, A. and S. Ardagna (1998). Fiscal adjustments. Why they can be expansionary. Economic Policy, 13, 489-545.

[4] Alesina, A. and R. Perotti (1995). Fiscal expansions and adjustments in 
OECD countries. Economic Policy, 10, 207-248.

[5] Alesina, A. and R. Perotti (1996). Fiscal Adjustments in OECD countries: composition and macroeconomic effects. NBER Working Paper 5730, August 1996.

[6] Ardagna, S. (2004). Fiscal stabilizations: When do they work and why. European Economic Review vol. 48, No. 5, pp. 1047-1074.

[7] Banerjee A., Dolado J., Galbraith J.W. and Hendry D.F. (1993), Cointegration, Error-correction and the Econometric Analysis of Nonstationary Data, Oxford University Press, 1993.

[8] Bertola, G. and A. Drazen (1993). Trigger points and budget cuts: explaining the effects of fiscal austerity. American Economic Review, 83, $11-26$.

[9] Blanchard, O. and R. Perotti (2002). An empirical characterization of the dynamic effects of changes in government spending and taxes on output. Quarterly Journal of Economics, 117, 1329-1368.

[10] Bohn H. (1991). Budget balance through revenue or spending adjustments? Some historical evidence for the United States. Journal of Monetary Economics, 27, 333-359.

[11] Bohn H. (2006), "Are Stationarity and Cointegration restrictions Really Necessary for the Intertemporal Budget Constraint?", forthcoming Journal of Monetary Economics.

[12] Bohn H. (2008), "The Sustainability of Fiscal Policy in the United States", in Neck R. and Sturm J., (eds.), Sustainability of Public Debt, Cambridge, MIT Press.. 
[13] Brock, W.A., W. Dechert and J. Scheinkman (1996). A test for independence based on the correlation dimension. Econometric Reviews, 15, 197-235.

[14] Chortareas G., Kapetanios G. and Uctum M. (2008) "Nonlinear Alternatives to Unit Root Tests and Public Finances Sustainability: Some Evidence from Latin American and Caribbean Countries," Oxford Bulletin of Economics and Statistics, 70(5), 645-663.

[15] Daveri, F. and G. Tabellini (2000). Unemployment, growth and taxation in industrial countries. Economic Policy, 15, 48-104.

[16] Dickey D.A. and Fuller W.A. (1979), "Distribution of the Estimators for Autoregressive Time Series with a Unit Root", Journal of the American Statistical Association, 74, 427-431.

[17] Doornik, J.A. and D.F. Hendry (2000). Modelling Dynamic Systems Using PcGive, Volume II, Timberlake Consultants Ltd.

[18] Escribano, A. (1986). Identification and modelling of economic relationships in a growing economy. $\mathrm{PhD}$ thesis, University of California, San Diego.

[19] Escribano, A. (2004). Non-linear error correction: the case of money demand in the U.K. (1878-2000). Macroeconomic Dynamics, 8, February issue.

[20] Escribano, A. and F. Aparicio (1999). Cointegration: linearity, nonlinearity, outliers and structural breaks in Dahiya, S.B. (ed), The Current State of Economic Science, Spellbound Publications, Vol 1, 383-407.

[21] Escribano, A. and C.W.J. Granger (1998). Investigating the relationship between gold and silver prices. Journal of Forecasting, 17, 81-107. 
[22] Escribano, A. and S. Mira (2002). Non-linear error correction models. Journal of Time Series Analysis, 23, 509-522.

[23] Escribano, A. and G.A. Pfann (1998). Nonlinear error correction, asymmetric adjustment and cointegration. Economic Modelling, 15, 197-216.

[24] Feve P. and Henin P.Y. (2000), Assessing Effective Sustainability of Fiscal Policy within the G-7, Oxford Bulletin of Economics and Statistics, 62(2), 175-195.

[25] Galli E. and F. Padovano (2008). Sustainability and Determinants of Italian Public Deficits before and after Maastricht, in Neck R. and Sturm J., (eds.), Sustainability of Public Debt, Cambridge, MIT Press.

[26] Giavazzi F., Jappelli T. and Pagano M. (2000), "Searching for Non-Linear Effects of Fiscal Policy: Evidence from Industrial and Developing Countries", European Economic Review, vol. 44, no.7, June 2000.

[27] Granger, C.W.J. and T.H. Lee (1989). Investigation of production, sales and inventory relationships using multicointegration and non-symmetric error correction models. Journal of Applied Econometrics, 4, S145-S159.

[28] Greiner A, Köller U. and Semmler W. (2007). "Debt sustainability in the European Monetary Union: Theory and empirical evidence for selected countries," Oxford Economic Papers, Oxford University Press, vol. 59(2), 194-218.

[29] Grilli, V., D. Masciandaro and G. Tabellini (1991). Political and Monetary Institutions and Public Financial Policies in Industrial Countries, Economic Policy, 6, 342-92.

[30] Hakkio, G. and M. Rush (1991). Is the budget deficit too large?. Economic 
Inquiry, 29, 429-445.

[31] Hamilton, J. and M. Flavin (1986). On the limitations of government borrowing: a framework for empirical testing. American Economic Review, $76,808-819$.

[32] Johansen, S. (1988). Statistical analysis of cointegration vectors. Journal of Economic Dynamics and Control, 12, 231-254.

[33] Koren, S. and A. Stiassny (1998). Tax and spend, or spend and tax? An international study. Journal of Policy Modeling, 20, 163-191.

[34] Kwiatkpwsiki D., Phillips P.C.B., Schmidt T. P. and Shin Y. (1992), "Testing the Null Hypothesis of Stationarity against the Alternative of a Unit Root", Journal of Econometrics, 54, 159-178.

[35] Leachman L., Bester A., Rosas G. and Lange P. (2005), "Multicointegration and Sustainability of Fiscal Practices", Economic Inquiry, 43(2), 454466.

[36] Legrenzi, G. and C. Milas (2002). The role of omitted variables in identifying a long-run equilibrium for the Italian government growth. International Tax and Public Finance, 9(4), 435-49.

[37] MacKinnon, J.G., A.A. Haug and L. Michelis (1999). Numerical distribution functions of likelihood ratio tests for cointegration. Journal of Applied Econometrics, 14, 563-577.

[38] Ng S. and Perron P. (2001), "Lag length Selection and the Construction of Unit Root Tests with Good Size and Power", Econometrica 69(6), 1519-1554.

[39] OECD (2005). Economic surveys: Italy, Paris. 
[40] Peacock, A.T. and J. Wiseman (1979). Approaches to the analysis of government expenditures growth. Public Finance Quarterly, 7, 3-23.

[41] Perotti R. (1999). Fiscal policy in good times and bad. Quarterly Journal of Economics, 114, 1399-1436.

[42] Pesaran, M.H. and Y.S. Shin (1996). Cointegration and speed of convergence to equilibrium. Journal of Econometrics, 71, 117-143.

[43] Phillips, P.C.B. and B.E. Hansen (1990). Statistical inference in instrumental variables regressions with I(1) processes. Review of Economic Studies, 57, 99-125.

[44] Phillips P.C.B. and Perron P. (1988), "Testing for a Unit Root in Time Series Regression", Biometrika 75, 335-346.

[45] Quintos, C.E. (1995). Sustainability of the deficit process with structural shifts. Journal of Business \&3 Economic Statistics, 13, 409-417.

[46] Reviglio, F. (2001). Budgetary Transparency for Public expenditure Control. IMF Working Paper 01/8.

[47] Roubini, N. and J. Sachs (1989). Political and economic determinants of budget deficits in the industrial democracies. European Economic Review, 33, 903-33.

[48] Sarno, L. (2001). The behavior of US public debt: a nonlinear perspective. Economics Letters, 74, 119-125.

[49] Schneider F. and D.H. Enste (2000). Shadow economies: size, causes and consequences. Journal of Economic Literature, 38, 77-114.

[50] Sutherland, A. (1997). Fiscal crises and aggregate demand: can high public debt reverse the effects of fiscal policy?, Journal of Public Economics, 
$65,147-162$.

[51] Teräsvirta, T. (1998). Comment on "The demand for broad money in the United Kingdom, 1878-1993" by Ericsson, N.R., D.F. Hendry and K.M. Prestwich, Scandinavian Journal of Economics, 100, 325-328.

[52] Trehan, B. and C. Walsh (1988). Common trends, the government budget constraint, and revenue smoothing. Journal of Economic Dynamics and Control, 12, 425-444.

[53] Trehan, B. and C. Walsh (1991). Testing Intertemporal Budget Constraints: Theory and Applications to the U.S. Federal Budget and Current Account Deficits. Journal of Money, Credit and Banking 23, 210-223.

[54] Uctum M., Thurston T. and Uctum R. (2006), "Public Debt: the Unit Root Hypothesis and Structural Breaks: A Multi-Country Analysis", Economica 73(289), 129-156.

[55] Uctum M. and Wickens M. (2000). Debt and deficit Celings, and Sustainability of Fiscal Policy: An Intertemporal Analysis. Oxford Bulletin of Economics and Statistics 62, 197-222.

[56] Walsh C.E. (2003), Monetary Theory and Policy. MIT Press, Cambridge.

[57] Wilcox, D.W. (1989). The Sustainability of Government deficits: Implications of the Present Value Constraint", Journal of Money Credit and Banking, 21, 291-306. 


\section{Data Appendix}

The data used for this paper are taken from the annual macro-economic database of the European Commission's Directorate General for Economic and Financial Affairs (AMECO).

The statistical definitions of the series are:

TAX: Total revenue; general government; ESA 1995 (URTG)

Total government revenue is the sum of: Sales of market output (ESA 95code P.11) and output- for own final use (P.12) + Payments for other non-market output (P.131) + Other subsidies on production (D.39), receivable + Taxes on production and imports (D.2), receivable + Property income (D.4), receivable + Current taxes on income and wealth (D.5), receivable + Social contributions (D.61), receivable + Other current transfers (D.7), receivable + Capital transfers (D.9), receivable.

G:Total expenditure; general government; ESA 1995 (UUTG)

Total general government expenditure is the sum of: Intermediate consumption (P.2) + Gross capital formation (P.5) + Compensation of employees (D.1), payable + Other taxes on production (D.29), payable + Subsidies (D.3), payable + Property income (D.4), payable + Current taxes on income and wealth (D.5), payable + Social benefits other than social transfers in kind (D.62), payable + Social transfers in kind related to expenditure on products supplied to households via market producers (D.6311 + D.63121 + D.63131), payable + Other current transfers (D.7), payable + Adjustment for the change in the net equity of households on pension funds reserves (D.8) ${ }^{13}$ + Capital transfers (D.9),

\footnotetext{
${ }^{13}$ The adjustment for the change in net equity of households in pension funds reserves (D.8) represents the adjustment needed to make appear in the saving of households the change in the actuarial reserves on which households have a definite claim. Accordingly, it is part of the expenditure of the insurance enterprises sector and other sectors administering nonautonomous pension funds (see ESA 1995, paragraph 4.141 and 4.144).
} 
payable + Acquisitions of non-produced non-financial assets (K.2)

GDP: GDP (reference level for excessive deficit procedure)

Gross domestic product at current market prices ; Reference level for excessive deficit procedure (UVGDH). 
Table 1: OLS estimates of alternative error correction models for $\triangle T A X$

\begin{tabular}{|c|c|c|c|}
\hline & (i) & (ii) & (iii) \\
\hline & Linear model & Asymmetric model & Non-linear model \\
\hline Constant & $0.003(2.120)$ & $0.002(0.535)$ & $0.005(0.825)$ \\
\hline$\Delta G O V_{t}$ & $0.234(2.572)$ & 0.236 (1.960) & $0.260(2.051)$ \\
\hline$C V_{t-1}$ & $-0.100(-2.818)$ & - & $0.010(0.100)$ \\
\hline $\mathrm{CV}^{2}{ }_{t-1}$ & - & - & $-0.131(0.970)$ \\
\hline $\mathrm{CV}^{3}{ }_{t-1}$ & - & - & $-39.239(-3.062)$ \\
\hline $\mathrm{CV}^{+}{ }_{t-1}$ & - & $-0.050(-0.740)$ & - \\
\hline $\mathrm{CV}^{-}{ }_{t-1}$ & - & $-0.132(-1.770)$ & - \\
\hline$\Delta^{2} G D P_{t-1}$ & & & $0.231(1.032)$ \\
\hline \multicolumn{4}{|l|}{ Diagnostics } \\
\hline Regression s.e. & 0.010 & 0.008 & 0.001 \\
\hline$\overline{R^{2}}$ & 0.255 & 0.290 & 0.330 \\
\hline Far & $0.41[0.66]$ & $0.48[0.61]$ & $0.67[0.51]$ \\
\hline Farch & $0.08[0.76]$ & $0.03[0.86]$ & $0.74[0.39]$ \\
\hline$\chi^{2} n d$ & $4.56[0.10]$ & $1.11[0.37]$ & $5.47[0.06]$ \\
\hline $\begin{array}{l}F \text { test of equal } C^{+} V_{t-1} \\
\text { and } C V_{t-1}^{-} \text {effects }\end{array}$ & - & $0.72[0.38]$ & - \\
\hline $\begin{array}{l}F \text { test of zero effect } \\
\text { from } \mathrm{CV}_{t-1}^{3}\end{array}$ & - & - & $8.98[0.00]$ \\
\hline $\begin{array}{l}F \text { test of zero effects } \\
\text { from } C V_{t-1}^{2} \text { and } C V_{t-1}^{3}\end{array}$ & - & - & $4.72[0.01]$ \\
\hline
\end{tabular}

Notes: t-ratios in parentheses. Far is the Lagrange Multiplier F-test for $2^{\text {nd }}$ order serial correlation. Farch is the $1^{\text {st }}$ order ARCH F-test. $\chi^{2} n d$ is a Chi-square test for normality. Numbers in square brackets are the $p$ values of the tests. $\overline{R^{2}}$ is the adjusted coefficient of determination. $C V=T A X-G O V$, in mean corrected form. 
Figure 1: Plots of the levels and the first differences of the series
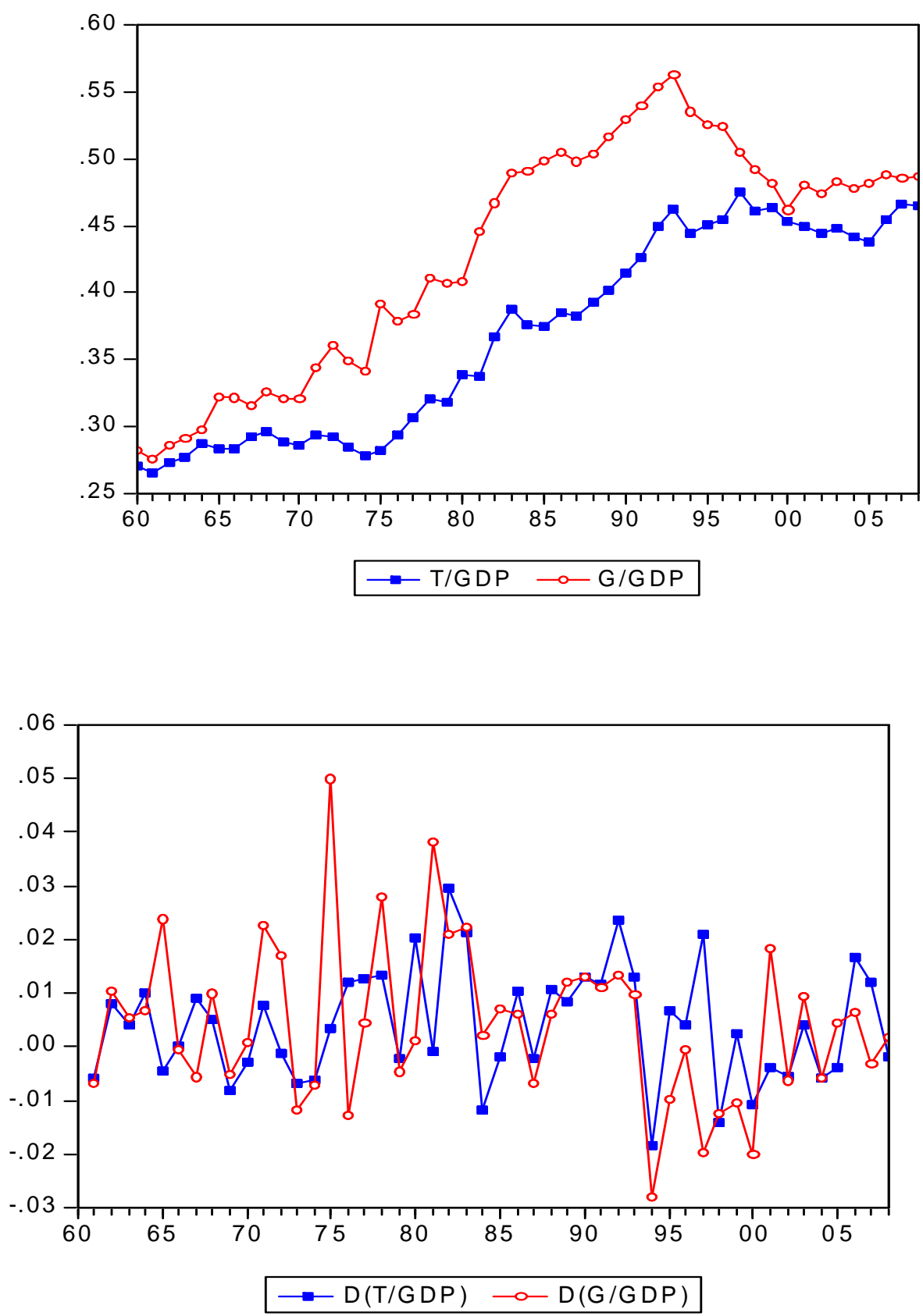
Figure 2: Long-run relationship: $C V=T A X-G O V$, in mean corrected form

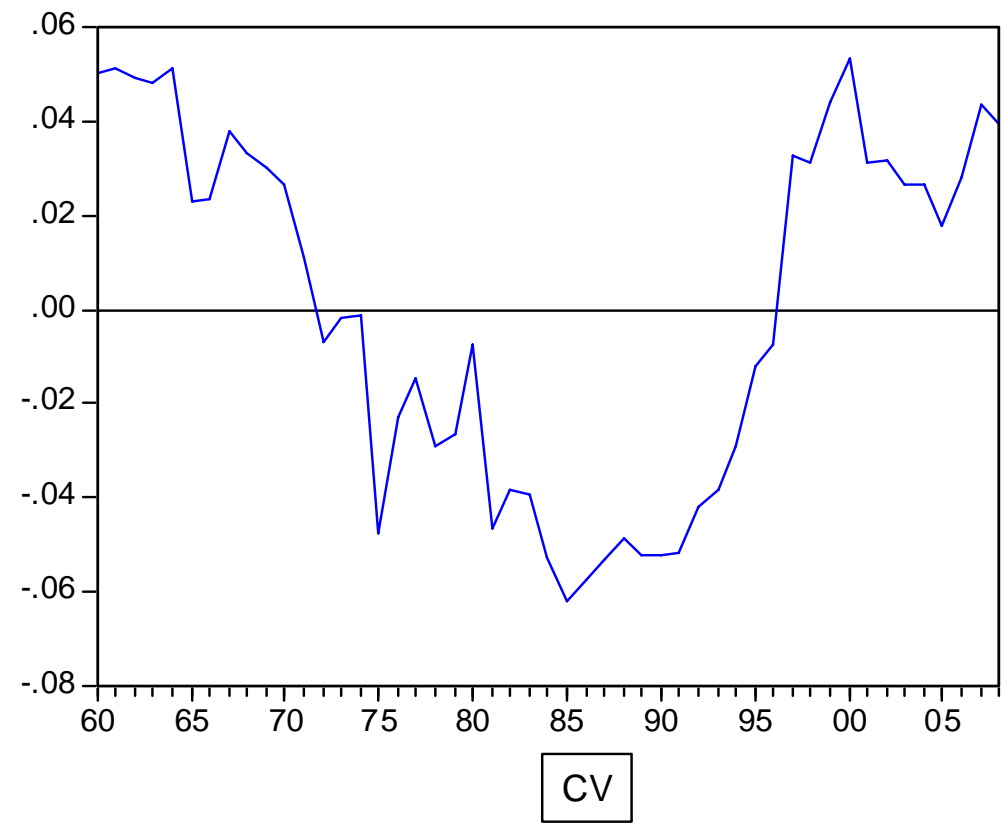

Figure 3: Trace and max test statistics divided by the corresponding $5 \%$ critical values

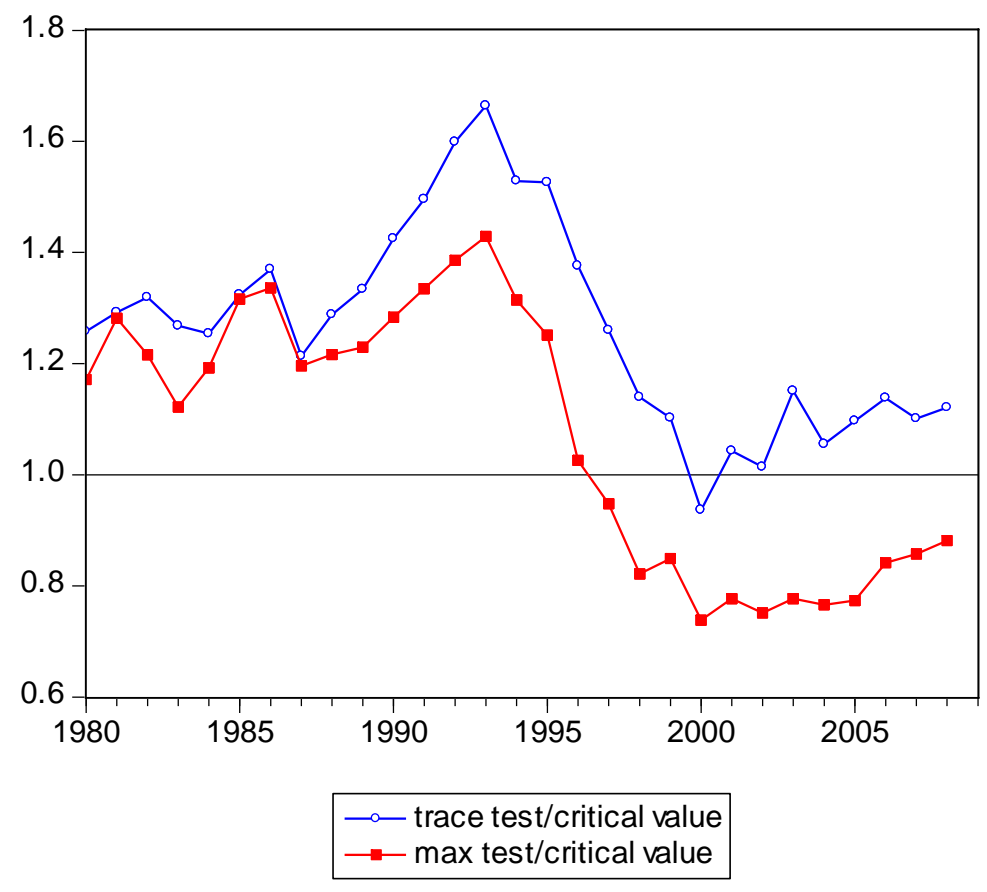


Figure 4: Recursive beta coefficient $\pm 2{ }^{*}$ standard errors

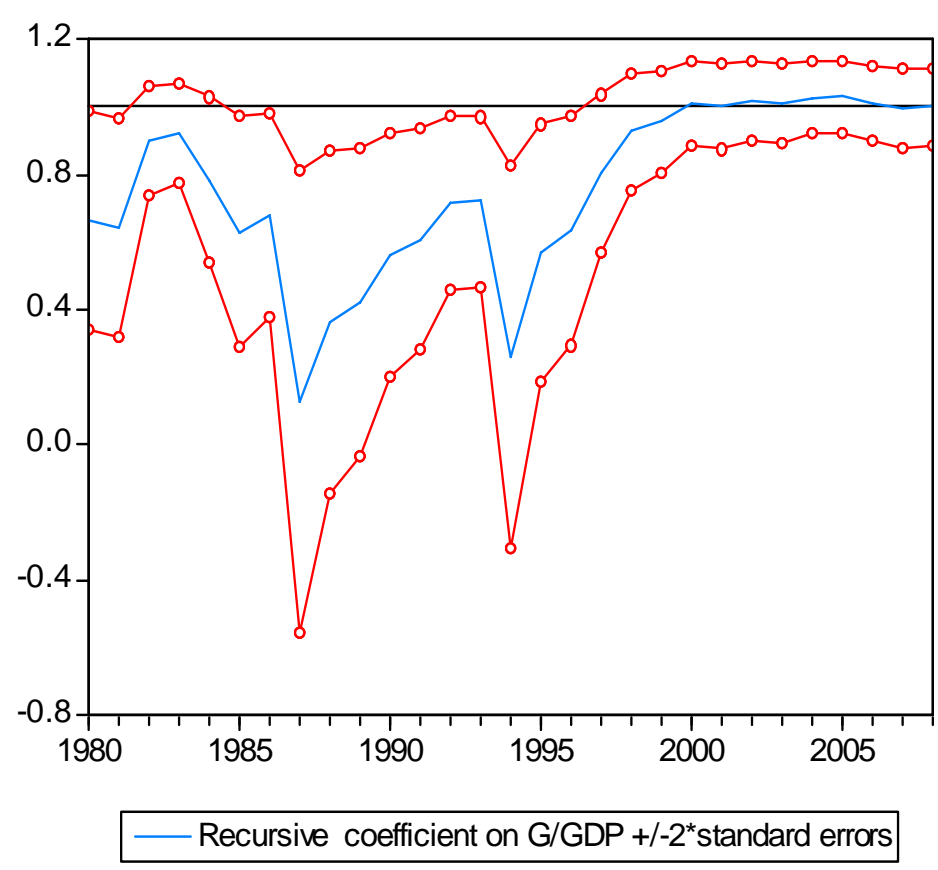

Figure 5: Persistence profile of the cointegrating vector to system-wide shocks

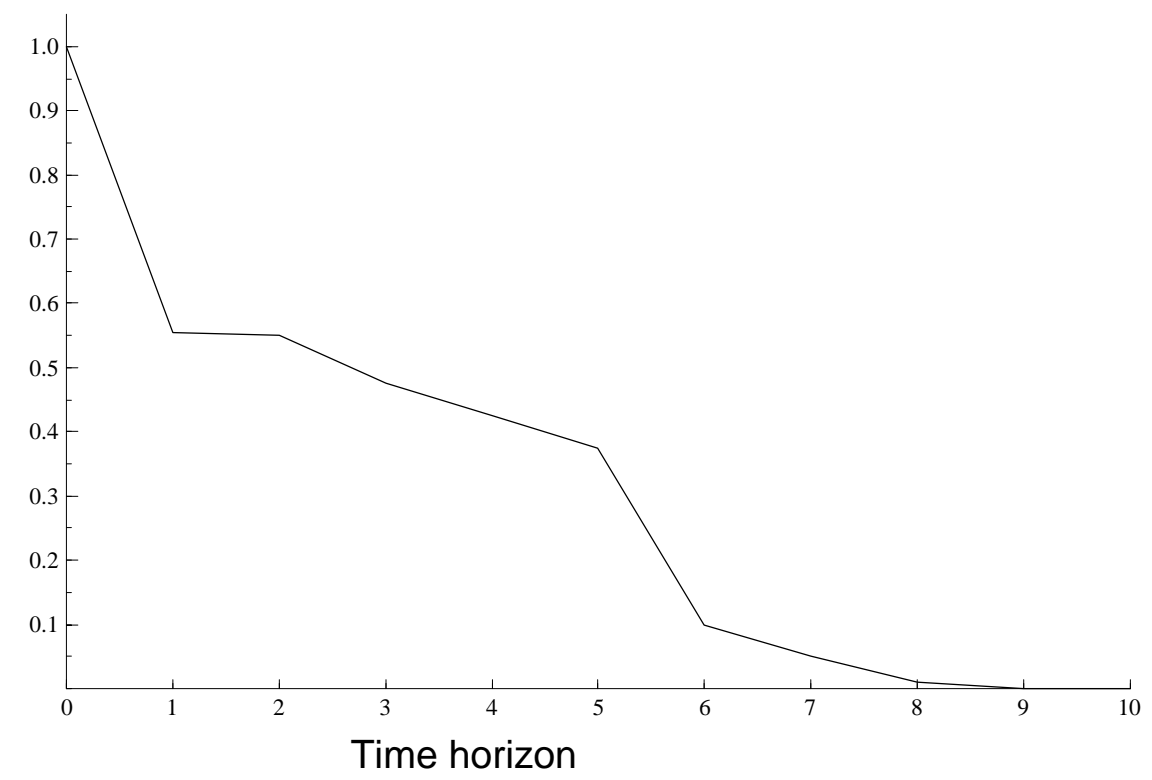


Figure 6: Asymmetric and non-linear adjustment

(a)

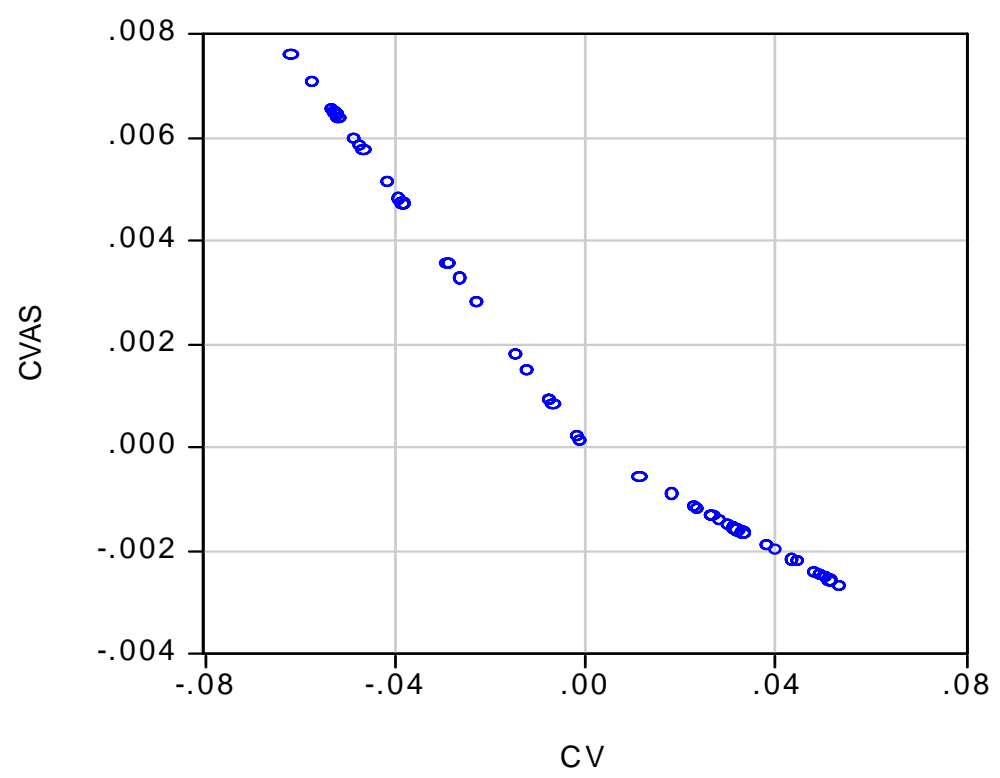

(b)

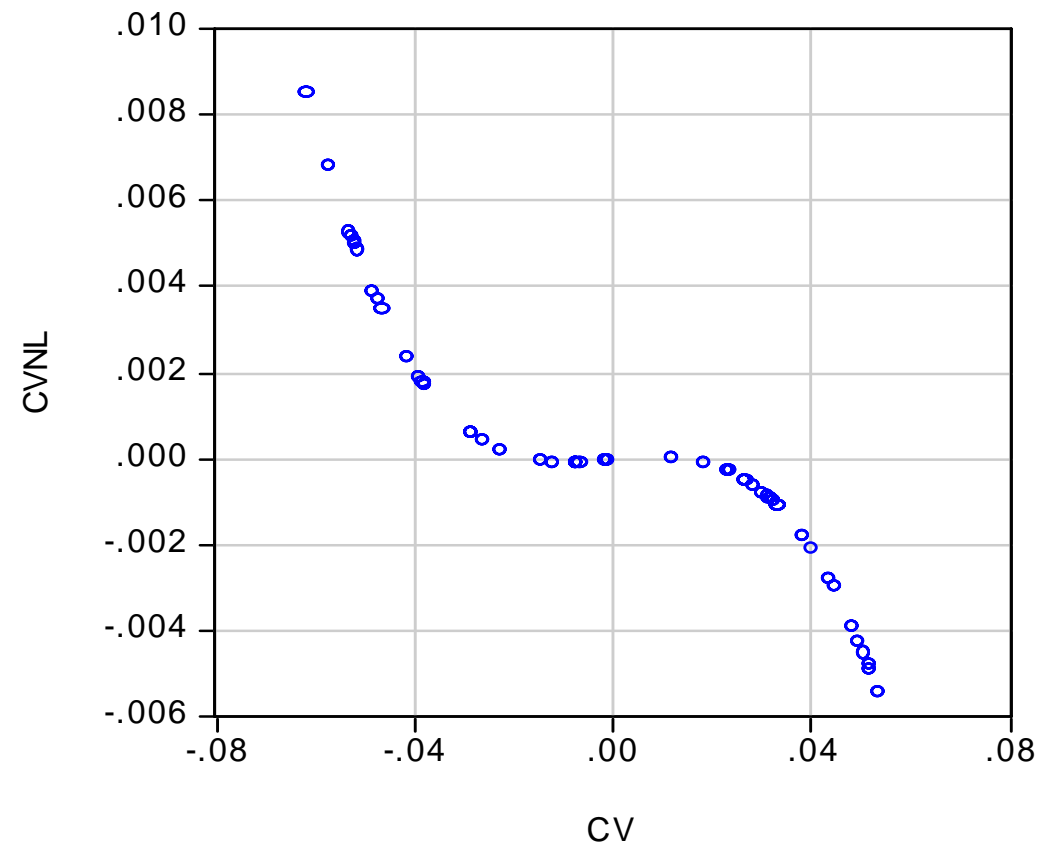

Notes: CVAS $=-0.050 \mathrm{CV}^{+}-0.132 \mathrm{CV}, \mathrm{CVNL}=0.010 \mathrm{CV}-0.131 \mathrm{CV}^{2}-39.239 \mathrm{CV}^{3}$. 
Figure 7: Error correction components of the linear, asymmetric and non-linear models for $\triangle T A X$

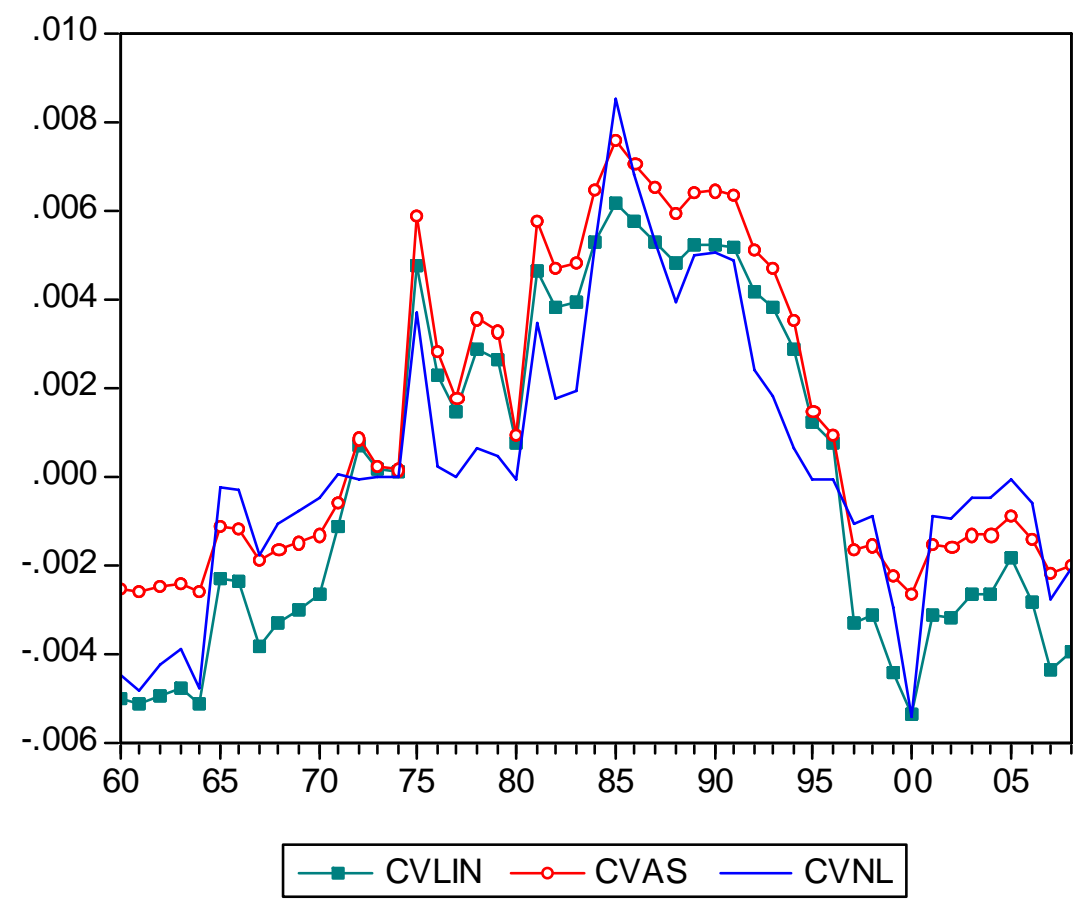

Notes: CVAS $=-0.050 \mathrm{CV}^{+}-0.132 \mathrm{CV}, \mathrm{CVNL}=0.010 \mathrm{CV}-0.131 \mathrm{CV}^{2}-39.239 \mathrm{CV}^{3}$, CVLIN $=-0.100 \mathrm{CV}$ 


\section{CESifo Working Paper Series}

for full list see www.cesifo-group.org/wp

(address: Poschingerstr. 5, 81679 Munich, Germany, office@cesifo.de)

2865 Torfinn Harding and Beata Smarzynska Javorcik, A Touch of Sophistication: FDI and Unit Values of Exports, December 2009

2866 Matthias Dischinger and Nadine Riedel, There's no Place like Home: The Profitability Gap between Headquarters and their Foreign Subsidiaries, December 2009

2867 Andreas Haufler and Frank Stähler, Tax Competition in a Simple Model with Heterogeneous Firms: How Larger Markets Reduce Profit Taxes, December 2009

2868 Steinar Holden, Do Choices Affect Preferences? Some Doubts and New Evidence, December 2009

2869 Alberto Asquer, On the many Ways Europeanization Matters: The Implementation of the Water Reform in Italy (1994-2006), December 2009

2870 Choudhry Tanveer Shehzad and Jakob De Haan, Financial Reform and Banking Crises, December 2009

2871 Annette Alstadsæter and Hans Henrik Sievertsen, The Consumption Value of Higher Education, December 2009

2872 Chris van Klaveren, Bernard van Praag and Henriette Maassen van den Brink, Collective Labor Supply of Native Dutch and Immigrant Households in the Netherlands, December 2009

2873 Burkhard Heer and Alfred Maußner, Computation of Business-Cycle Models with the Generalized Schur Method, December 2009

2874 Carlo Carraro, Enrica De Cian and Massimo Tavoni, Human Capital Formation and Global Warming Mitigation: Evidence from an Integrated Assessment Model, December 2009

2875 André Grimaud, Gilles Lafforgue and Bertrand Magné, Climate Change Mitigation Options and Directed Technical Change: A Decentralized Equilibrium Analysis, December 2009

2876 Angel de la Fuente, A Mixed Splicing Procedure for Economic Time Series, December 2009

2877 Martin Schlotter, Guido Schwerdt and Ludger Woessmann, Econometric Methods for Causal Evaluation of Education Policies and Practices: A Non-Technical Guide, December 2009

2878 Mathias Dolls, Clemens Fuest and Andreas Peichl, Automatic Stabilizers and Economic Crisis: US vs. Europe, December 2009 
2879 Tom Karkinsky and Nadine Riedel, Corporate Taxation and the Choice of Patent Location within Multinational Firms, December 2009

2880 Kai A. Konrad, Florian Morath and Wieland Müller, Taxation and Market Power, December 2009

2881 Marko Koethenbuerger and Michael Stimmelmayr, Corporate Taxation and Corporate Governance, December 2009

2882 Gebhard Kirchgässner, The Lost Popularity Function: Are Unemployment and Inflation no longer Relevant for the Behaviour of Germany Voters?, December 2009

2883 Marianna Belloc and Ugo Pagano, Politics-Business Interaction Paths, December 2009

2884 Wolfgang Buchholz, Richard Cornes and Dirk Rübbelke, Existence and Warr Neutrality for Matching Equilibria in a Public Good Economy: An Aggregative Game Approach, December 2009

2885 Charles A.E. Goodhart, Carolina Osorio and Dimitrios P. Tsomocos, Analysis of Monetary Policy and Financial Stability: A New Paradigm, December 2009

2886 Thomas Aronsson and Erkki Koskela, Outsourcing, Public Input Provision and Policy Cooperation, December 2009

2887 Andreas Ortmann, "The Way in which an Experiment is Conducted is Unbelievably Important": On the Experimentation Practices of Economists and Psychologists, December 2009

2888 Andreas Irmen, Population Aging and the Direction of Technical Change, December 2009

2889 Wolf-Heimo Grieben and Fuat Şener, Labor Unions, Globalization, and Mercantilism, December 2009

2890 Conny Wunsch, Optimal Use of Labor Market Policies: The Role of Job Search Assistance, December 2009

2891 Claudia Buch, Cathérine Tahmee Koch and Michael Kötter, Margins of International Banking: Is there a Productivity Pecking Order in Banking, too?, December 2009

2892 Shafik Hebous and Alfons J. Weichenrieder, Debt Financing and Sharp Currency Depreciations: Wholly vs. Partially Owned Multinational Affiliates, December 2009

2893 Johannes Binswanger and Daniel Schunk, What is an Adequate Standard of Living during Retirement?, December 2009

2894 Armin Falk and James J. Heckman, Lab Experiments are a Major Source of Knowledge in the Social Sciences, December 2009 
2895 Hartmut Egger and Daniel Etzel, The Impact of Trade on Employment, Welfare, and Income Distribution in Unionized General Oligopolistic Equilibrium, December 2009

2896 Julian Rauchdobler, Rupert Sausgruber and Jean-Robert Tyran, Voting on Thresholds for Public Goods: Experimental Evidence, December 2009

2897 Michael McBride and Stergios Skaperdas, Conflict, Settlement, and the Shadow of the Future, December 2009

2898 Ben J. Heijdra and Laurie S. M. Reijnders, Economic Growth and Longevity Risk with Adverse Selection, December 2009

2899 Johannes Becker, Taxation of Foreign Profits with Heterogeneous Multinational Firms, December 2009

2900 Douglas Gale and Piero Gottardi, Illiquidity and Under-Valuation of Firms, December 2009

2901 Donatella Gatti, Christophe Rault and Anne-Gaël Vaubourg, Unemployment and Finance: How do Financial and Labour Market Factors Interact?, December 2009

2902 Arno Riedl, Behavioral and Experimental Economics Can Inform Public Policy: Some Thoughts, December 2009

2903 Wilhelm K. Kohler and Marcel Smolka, Global Sourcing Decisions and Firm Productivity: Evidence from Spain, December 2009

2904 Marcel Gérard and Fernando M. M. Ruiz, Corporate Taxation and the Impact of Governance, Political and Economic Factors, December 2009

2905 Mikael Priks, The Effect of Surveillance Cameras on Crime: Evidence from the Stockholm Subway, December 2009

2906 Xavier Vives, Asset Auctions, Information, and Liquidity, January 2010

2907 Edwin van der Werf, Unilateral Climate Policy, Asymmetric Backstop Adoption, and Carbon Leakage in a Two-Region Hotelling Model, January 2010

2908 Margarita Katsimi and Vassilis Sarantides, Do Elections Affect the Composition of Fiscal Policy?, January 2010

2909 Rolf Golombek, Mads Greaker and Michael Hoel, Climate Policy without Commitment, January 2010

2910 Sascha O. Becker and Ludger Woessmann, The Effect of Protestantism on Education before the Industrialization: Evidence from 1816 Prussia, January 2010

2911 Michael Berlemann, Marco Oestmann and Marcel Thum, Demographic Change and Bank Profitability. Empirical Evidence from German Savings Banks, January 2010 
2912 Øystein Foros, Hans Jarle Kind and Greg Shaffer, Mergers and Partial Ownership, January 2010

2913 Sean Holly, M. Hashem Pesaran and Takashi Yamagata, Spatial and Temporal Diffusion of House Prices in the UK, January 2010

2914 Christian Keuschnigg and Evelyn Ribi, Profit Taxation and Finance Constraints, January 2010

2915 Hendrik Vrijburg and Ruud A. de Mooij, Enhanced Cooperation in an Asymmetric Model of Tax Competition, January 2010

2916 Volker Meier and Martin Werding, Ageing and the Welfare State: Securing Sustainability, January 2010

2917 Thushyanthan Baskaran and Zohal Hessami, Globalization, Redistribution, and the Composition of Public Education Expenditures, January 2010

2918 Angel de la Fuente, Testing, not Modelling, the Impact of Cohesion Support: A Theoretical Framework and some Preliminary Results for the Spanish Regions, January 2010

2919 Bruno S. Frey and Paolo Pamini, World Heritage: Where Are We? An Empirical Analysis, January 2010

2920 Susanne Ek and Bertil Holmlund, Family Job Search, Wage Bargaining, and Optimal Unemployment Insurance, January 2010

2921 Mariagiovanna Baccara, Allan Collard-Wexler, Leonardo Felli and Leeat Yariv, Gender and Racial Biases: Evidence from Child Adoption, January 2010

2922 Kurt R. Brekke, Roberto Cellini, Luigi Siciliani and Odd Rune Straume, Competition and Quality in Regulated Markets with Sluggish Demand, January 2010

2923 Stefan Bauernschuster, Oliver Falck and Niels Große, Can Competition Spoil Reciprocity? - A Laboratory Experiment, January 2010

2924 Jerome L. Stein, A Critique of the Literature on the US Financial Debt Crisis, January 2010

2925 Erkki Koskela and Jan König, Profit Sharing, Wage Formation and Flexible Outsourcing under Labor Market Imperfection, January 2010

2926 Gabriella Legrenzi and Costas Milas, Spend-and-Tax Adjustments and the Sustainability of the Government's Intertemporal Budget Constraint, January 2010 